\title{
Articles
}

\section{Failed Expectations: Does the Establishment of Judicial Councils Enhance Confidence in Courts?}

\author{
By Marína Urbániková* \& Katarína Šipulová ${ }^{* *}$
}

\begin{abstract}
Judicial councils are often presented as a panacea for many disorders of judicial systems, including low public confidence in the judiciary. Nevertheless, the assessment of their impact has so far been neglected. The article offers a unique view on the relationship between judicial councils and the level of public confidence in courts. It draws a novel conceptual map of factors influencing public confidence in the judiciary, stressing its complex and multifaceted character. Situating the judicial councils on the map, it explores how they can help to potentially increase the level of public confidence in the judiciary, and assesses to what extent this has been true in the countries that have adopted them. The results reveal a considerable gap between the promises, expectations, and practice, and raise doubts about the ability of judicial councils to enhance confidence in courts. Judicial councils rarely manage to substantially improve institutional performance: they can enhance the quality of judicial systems which have already functioned quite well, but they do not tend to bring about change in the judicial systems that have been previously significantly flawed. The analysis of the longitudinal Eurobarometer data showed that, on average, the EU countries without judicial councils are better off in terms of public confidence. Although the existence of judicial councils does not make a difference regarding public confidence in the judiciary in the new EU member states, in the old EU member states, judicial systems with judicial councils enjoy lower levels of public confidence than the ones without them.
\end{abstract}

\footnotetext{
* Marína Urbániková is a senior researcher at the Judicial Studies Institute, Masaryk University, an assistant professor at the Faculty of Social Studies, Masaryk University, and the head of research unit at the Office of the Public Defender of Rights of the Czech Republic. Email: m.urbanikova@mail.muni.cz. ORCID: 0000-0003-16409823. The research leading to this article has received funding from the European Research Council (ERC) under the European Union's Horizon 2020 research and innovation programme (grant no. 678375- JUDI-ARCH-ERC2015-STG).

** Katarína Šipulová is a senior researcher at the Judicial Studies Institute, Masaryk University, and external advisor in EU law at the Supreme Court of the Czech Republic. Email: katarina.sipulova@law.muni.cz. ORCID: 0000-0002-3593-3594.
} 


\section{A. Introduction}

Since 1989, Europe has witnessed a boom of judicial councils, i.e. institutions which transferred various decision-making powers regarding judicial self-government from politicians to judges and political nominees. This wave built on diverse motives: some countries hoped to foster the efficiency and efficacy of judicial systems, while others believed that judicial councils would help enhance the independence, accountability, or legitimacy of domestic courts. All in all, the judicial councils were believed to enhance the working of the courts and, depending on their success, enhance public confidence in the judiciary, as well. Despite judicial councils being eventually established in most European countries, we know in fact very little about how they have performed. Following various case studies presented in this Special Issue, this article zeroes in on judicial councils as a possible determinant of public confidence in the judiciary.

Surprisingly, although public confidence is frequently identified as one of the goals of judicial councils, legal scholarship has so far largely neglected this phenomenon. Having the confidence of the public is of fundamental importance for the judiciary. Public confidence links ordinary citizens to the institutions that are intended to serve them. The public perception that courts provide basic protections to individuals and serve as independent and impartial tribunals to resolve disputes is essential for the effective performance of the judicial function. If the citizens do not trust the courts, they may not accept judicial decisions and may resort to other means to resolve their disputes. Thus, without public confidence in the judiciary, its ability to provide justice is compromised, which can have far-reaching consequences for the rule of law, stability of democracy, and social order. Moreover, the perception of the quality of the judicial system has lately gained significance, since it can determine the transnational activities of citizens and enterprises.

The vital significance of public confidence in judges, courts, and the judiciary is widely acknowledged by various stakeholders on both the national and international levels. For instance, ethical codes of judicial conduct usually state that judges are supposed to maintain public confidence and should not do anything that would undermine it (for example, the Preamble of Bangalore Principles of Judicial Conduct states that public confidence in the judicial system and in the moral authority and integrity of the judiciary is of the utmost importance in a modern democratic society). ${ }^{1}$ Furthermore, public confidence is one of the indicators commonly used for the assessment of judiciaries (e.g.,

\footnotetext{
${ }^{1}$ See also Bangalore Principles of Judicial Conduct of 2002, value 4 identifying the judges as a subject of constant public scrutiny; references to public confidence and the role of judges appear also in several national codes of conduct, e.g. General Council of the Judiciary (Spain). Principles of Judicial Ethics, 16 December 2016; United States Courts. Code of Conduct for United States Judges, http://www.uscourts.gov/judges-judgeships/codeconduct-united-states-judges.
} 
in CEPEJ reports ${ }^{2}$ or European Commission reports). ${ }^{3}$ Sustaining or enhancing public confidence in the judiciary is one of the goals declared by top judicial officials ${ }^{4}$ and often finds its place in new strategies, plans, reforms, and policies focusing on the judiciary across the globe. ${ }^{5}$ Although rather indirectly, references to public confidence can also be traced in the reasoning justifying the rise of the power of judges in court governance, which has been one of the most important and remarkable recent trends in the administration of judiciary. ${ }^{6}$

The establishment of judicial councils ${ }^{7}$ as a panacea for deficiencies of judicial systems has been strongly promoted by many international organizations. Both the Council of Europe (COE) and the European Union (EU) typically conditioned the successful accession of countries with the institutional transformation of judiciaries and the establishment of judicial councils as a model form of judicial self-government. ${ }^{8}$ The argumentation substantiating the transfer of powers from politicians to judges was clear: establishing a judicial council was expected to strengthen the independence of the judiciary, and thus lead to a better working judicial system. The judicial councils were expected to be independent authorities, typically rooted in constitutions, overseeing the independence of courts and judges from political influence, while at the same time, guaranteeing their accountability, ${ }^{9}$ as well as the effectiveness ${ }^{10}$ and transparency of judicial systems, and fostering the rule of law principles. Consequently, this improvement should also be felt by

${ }^{2}$ E.g. Report of CEPEJ on European Judicial Systems (2016). https://www.uihj.com/en/publication-of-the-2016report-of-cepej-on-european-judicial-systems_2165915.html.

3 European Commission. Effective justice. https://ec.europa.eu/info/policies/justice-and-fundamentalrights/effective-justice_en.

${ }^{4}$ E.g. Committee for the Evaluation of the Modernisation of the Dutch Judiciary (2006). Judiciary is Quality. https://www.rechtspraak.nl/SiteCollectionDocuments/Judiciary-is-quality.pdf.

5 E.g. United States Courts. Enhancing Public Understanding, Trust, and Confidence. http://www.uscourts.gov/statistics-reports/issue-7-enhancing-public-understanding-trust-and-confidence. Or Public Service and Trust Commission (2008). Strategic Plan for the Judicial Branch. https://www.jud.ct.gov/Committees/pst/StrategicPlan.pdf.

${ }^{6}$ Kosař, David, Beyond Judicial Councils: Forms, Rationales and Impact of Judicial Self-Government in Europe in this issue.

${ }^{7}$ For a definition of a judicial council, see Kosař, id.

${ }^{8}$ Resolution of the General Assembly of the European Network of Councils for the judiciary (2008), Budapest, 2123 May, 2008; The European Network of Councils for the Judiciary (ENCJ): Council for the Judiciary Report 2010/2011. ENJC Project Team; Recommendation No. R (94) 12, Committee of Ministers.

${ }^{9}$ Christopher M. Larkins, Judicial Independence and Democratization: A Theoretical and Conceptual Analysis, 44 ASCL 605 (1996); Peter H. Russell ANd DaVid M. O’BRIEN, Judicial Independence IN THE Age of Democracy (2001).

${ }^{10}$ Recommendation CM/Rec (2010)12 of the Committee of Ministers to member states on judges: independence, efficiency and responsibilities, Committee of Ministers, 17 November 2010, para. 46. 
the users of the judicial system, i.e., by the general public, and thus be reflected in an increasing level of public confidence in the judiciary.

Given the high hopes regarding the establishment of judicial councils, the question then arises as to what extent they have been fulfilled. However, the literature on this topic is scarce, ${ }^{11}$ and systemic analysis of the relationship between the confidence in courts and judicial councils is still missing. ${ }^{12}$ Few existing studies focus predominantly on the relationship between judicial conduct and public confidence, ${ }^{13}$ let alone other possibly intervening factors.

Acknowledging the crucial importance of public confidence in the judiciary, this article explores both the potential and factual consequences of the establishment of judicial councils in this aspect. It aims to assess how judicial councils can enhance the level of public confidence in the judiciary, and to what extent this has been true in the countries that have adopted them. In order to do so, we created a novel concept map of public confidence that categorizes the main factors identified by existing research as potentially influential, and pinpoints the position of judicial councils among the determinants adding to public confidence at the institutional, individual, and cultural level. Based on national case studies presented in this Special Issue, complemented by longitudinal comparative Eurobarometer data, we argue that 1) citizens of both old and new EU member states have greater confidence in the judiciary than other branches of power, irrespective of the existence of judicial councils, 2) EU countries without judicial councils enjoy higher levels of public confidence in their judiciaries, and 3) while the existence of judicial councils does not make a substantive difference in the new EU countries, in the old EU member states they coincide with even lower levels of public confidence in the judiciary.

The paper proceeds as follows: Section B starts with an examination of expectations regarding the establishment of judicial councils, with a special focus on public confidence. It surveys both official documents and scientific literature and shows, although indirectly, that one of the rationales for the introduction of judicial councils has been the expected increase of public confidence. Section $C$ defines public confidence, explains its importance, summarizes the main theories explaining how it emerges, and reviews empirical studies

\footnotetext{
${ }^{11}$ Argument raised e.g. by Nuno Garoupa \& Tom Ginsburg, Guarding the Guardians: Judicial Councils and Judicial Independence, 57 Am. J. of Comp. Law 103 (2009).

${ }^{12}$ For some exemption see e.g. US or common law scholarship: Sara C. Benesh, Understanding Public Confidence in American Courts, The Journal of Politics 697 (2006). Sarah M. R. Cravens, Promoting Public Confidence in the Regulation of Judicial Conduct: A Survey of Recent Developments and Practices in Four Common Law Countries, 42 MCGEORGE LAW REVIEW 177-212 (2011).

${ }^{13}$ Cravens, supra note 12; Gregory A. Caldeira, Neither the Purse Nor the Sword: Dynamics of Public Confidence in the Supreme Court, 80 THE AMERICAN POLITICAL SCIENCE REVIEW 1209-1226 (1986), http://www.jstor.org/stable/1960864; Benesh Sara C., supra note 12.
} 
focusing on the determinants of public confidence in the judiciary. Section D explores both theoretical and empirical links between the establishment of judicial councils and the level of public confidence. First, it investigates the mechanism on the theoretical level. Second, based on the national case studies in this Special Issue, it reviews the extent to which judicial councils in ten ${ }^{14}$ countries fulfilled the expectations that were invested into them. Then, based on Eurobarometer data, it examines whether the judiciaries in the countries which have established judicial councils enjoy greater public confidence. Finally, the conclusion summarizes the main findings, offers tentative interpretations of these findings, reflects on the methodological limitations and suggests avenues for future research.

\section{B. Rationales Surrounding the Establishment of Judicial Councils: Did Public Confidence Matter?}

Post-war Europe restarted processes of judicial reform in nearly all transitioning democracies. The introduced changes mostly mirrored the general distrust towards concentrating power in the hands of one actor. ${ }^{15}$ Constitutional courts $^{16}$ and judicial councils symbolized the new institutions of democratic regimes, ${ }^{17}$ helping to rid the courts and judges of the political inference by the executive power. ${ }^{18}$ The following section aims to analyze the expectations put on the establishment of judicial councils regarding their impact on the public's confidence in the judiciary. The section looks at both primary national and international level documents and explores the presence of explicit, direct references on the enhancement of public confidence. It is important to stress that while this section identifies only explicit notions, empirical Section D also confronts these notions with expectations identified by the authors of individual case studies in this Special Issue.

\section{International Reports}

International documents, recommendations, and statutes only gradually began to reflect the relevance of the model of judicial self-government (JSG) for the public confidence in courts. The very first notion emerged in Bangalore Principles of Judicial Conduct of $2002{ }^{19}$

\footnotetext{
${ }^{14}$ France, Ireland, Italy, Netherlands, Poland, Romania, Slovakia, Slovenia, Spain, Turkey.

${ }^{15}$ Herman Schwartz, The Struggle for Constitutional Justice in Post-Communist Europe (2004).

16 Shortly after the WW2, constitutional courts were introduced in Austria, Germany, Italy, Greece, Spain, Portugal, Belgium, and France. Similar development followed after 1989 in post-communist countries.

${ }^{17}$ ODIHR. Judicial Independence in Eastern Europe, South Caucasus and Central Asia. Challenges, Reforms, and Way Forward. Meeting Report, 23-25 June 2010, https://www.osce.org/odihr/71178?download=true.

${ }^{18}$ Some authors however pointed out the risk of establishing judicial councils in countries which did not purify and screen the post-communist judiciaries. David Kosař, Perils OF JUdICIAL SElf-Government In TRANSITIONAL SOCIETIES (2016).

${ }^{19}$ THE BANGALORE PRINCIPLES, 2002, supra note 1 , at 11.
} 
The United Nations Judicial Group on Strengthening Judicial Integrity, which prepared the Principles later revised at the Round Table Meeting of Chief Justices in The Hague in 2002, strongly believed that judicial accountability and judicial independence would lead to a rise in the level of public confidence (in the rule of law). ${ }^{20}$ The Principles also identified different levels of confidence in the courts' activity, depending on the adequate information about the judiciary and its functions being available to citizens. ${ }^{21}$

Similarly, the Kyiv Recommendations on Judicial Independence in Eastern Europe, South Caucasus, and Central Asia $^{22}$ stressed the effect of administration on the facilitation of public trust in the courts, especially through establishing the court positions of press secretary or media officers.

The Council of Europe, very active in recommendations on JSG in post-communist Central and Eastern European countries, did not reflect on the question of public confidence in its 1994 Recommendation. ${ }^{23}$ Nevertheless, the restoration of public confidence emerged later on in objectives and action plans meaning to strengthen judicial independence and impartiality. ${ }^{24}$ The reference to the rise of public confidence as one of the effects of judicial councils later appeared in reports of the Venice Commission. ${ }^{25}$ The European Commission, on the contrary, identifies national justice systems as a key to restoring confidence, and the structural justice reforms (while advocating judicial councils) as an essential tool for effectiveness of national justice systems. ${ }^{26}$

Lastly, in 2017, the European Network of Judicial Councils adopted a report on public confidence, stressing that judicial councils, "in order to maintain the rule of law, must do all they can to ensure the maintenance of an open and transparent system of justice. Equally, an open and transparent system of justice is a further precondition for establishing

${ }^{20}$ Commentary on Bangalore Principles https://rm.coe.int/168066d6b9.

${ }^{21} / d$.

${ }^{22}$ OSCE and Max Planck Minerva Research Group on Judicial Independence. Kyiv Recommendations on Judicial Independence in Eastern Europe, South Caucasus and Central Asia, https://www.osce.org/odihr/KyivRec?down load=true.

${ }^{23}$ Council of Europe, Committee of Ministers, Recommendation No. R (94) 12 (1994) http://www.barobirlik.org. tr/dosyalar/duyurular/hsykkanunteklifi/recR(94)12e.pdf.

${ }^{24}$ Council of Europe Portal, https://www.coe.int/en/web/human-rights-rule-of-law/-/council-of-europe-launchesaction-plan-on-strengthening-judicial-independence-and-impartiality and Council of Europe, Plan of Action on Strengthening Judicial Independence and Impartiality CM(2016)36 https://rm.coe.int/1680700125.

${ }^{25}$ Venice Commission. Judicial Appointments. Discussion paper, 14 March 2007, http://www.venice.coe.int/ webforms/documents/default.aspx?pdffile=CDL-JD(2007)001-e.

${ }^{26}$ European Commission. https://ec.europa.eu/info/strategy/justice-and-fundamental-rights/effective-justice/ improving-effectiveness-national-justice-systems_en. 
and maintaining the Public trust in justice, which is a cornerstone of legitimacy of judiciary." ${ }^{27}$ The report identified several tools judicial councils could use to enhance public confidence.

In other words, international associations expected that judicial councils might enhance public confidence, but only gradually. Most international documents merely pointed to significant drops in public confidence in individual judiciaries or the importance of public confidence for the state and society as such. Still, the rise in confidence is implicitly expected to come with the creation of a more efficient judiciary - a task that was newly assigned to the judicial councils.

\section{National reports}

National reports, on the other hand, often indicate a pressing need for judicial system reform, which stems from a lack in public confidence. What these reports lack, however, is a clear understanding of why confidence is low or how the proposed changes would help to increase it. In general, references to public confidence in the judiciary appear at two stages: as a justification for either the establishment or the reform of a judicial council. In both instances, official domestic documents expected the judicial councils to either actively respond to lowering public confidence or they stressed the need to build and promote public confidence. Similarly to international documents, the rationale is only indirect: the potential success of judicial councils in strengthening the effectiveness, independence, accountability (etc.) of judiciaries should result in higher public confidence in the courts.

${ }^{27}$ European Network of Councils for the Judiciary. Public Confidence and the Image of Justice. Report 2017-2018. https://pgwrk-websitemedia.s3.eu-west-1.amazonaws.com/production/pwk-web-encj2017-

p/Reports/ENCJ_Report_Public_Confidence_2017_2018\%20adopted_\%20GA_1_June_2018.pdf. 
Table 1: Values acknowledged in national reports as conditioning the rise of public confidence, as identified in national reforms of judicial councils

(Source: authors)

\begin{tabular}{|l|l|l|l|}
\hline & Independence & Accountability & Effectiveness \\
\hline \multirow{2}{*}{ Establishment } & Netherlands $^{28}$ & Netherlands $^{29}$ & Netherlands $^{30}$ \\
\hline \multirow{2}{*}{ Reforms } & & & Belgium $^{31}$ \\
\hline & $\begin{array}{l}\text { Italy } \\
\text { Ireland }\end{array}$ & & France $^{32}$ \\
\hline & $\begin{array}{l}\text { Hungary } \\
\text { Poland }\end{array}$ & & \\
\hline & & & Ireland $^{35}$ \\
\hline
\end{tabular}

${ }^{28}$ Philip M. Langbroek, Reform of the Judiciary in the Netherlands. Some Lessons after the First 8 Years. World Bank Group, http://siteresources.worldbank.org/INTECA/Resources/ReformJudiciaryNetherlands.pdf.

${ }^{29}$ Id.

${ }^{30}$ Philip M. Langbroek, Organization Development of the Dutch Judiciary, between Accountability and Judicial Independence. IJCA:2 (April 2010).

${ }^{31}$ Le Conseil de la Justice, http://www.hrj.be/fr/content/historique.

${ }^{32}$ Conseil Superieur de la Magistrature, http://www.conseil-superieur-magistrature.fr/le-csm/histoire-etpatrimoine.

${ }^{33}$ La tutela dell'onore professionale e della dignità personale dei magistrati. L'esigenza di garantire il rispetto della funzione giudiziaria. Resolution of the CSM,15 December 1999; Renato Balduzzi, Inauguration of the Judicial Year 2015. 24 January 2015, https://www.csm.it/web/rbalduzzi/bacheca-del-consigliere/-/blogs/inaugurazione-dellanno-giudiziario-2015; Consiglio Superiore della Magistratura, https://www.csm.it/web/csm-internet/assistenzaal-cittadino.

${ }^{34}$ It is worth noting that focus on public confidence appears only in the new 2017 proposal. Department of Justice and Equality, Judicial Council Bill 2017 http://www.justice.ie/en/JELR/Judicial_Council_Bill_2017_Explanatory_ and_Financial_Memorandum.pdf/Files/Judicial_Council_Bill_2017_Explanatory_and_Financial_Memorandum.pdf

${ }^{35} / d$.

${ }^{36}$ IBAHRI. Still under threat: The independence of the judiciary and the rule of law in Hungary, 2015.

${ }^{37}$ https://www.premier.gov.pl/files/files/white_paper_en_full.pdf.

${ }^{38} / d$.

39 Le Conseil de la Justice, http://www.hrj.be/fr/content/communique-de-presse-le-conseil-superieur-de-lajustice-10-ans-apres-la-marche-blanche. The Belgian High Council of Justice. Presentation, http://www.hrj.be/sites/default/files/press_publications/o0026b.pdf. 
As already mentioned, national legal reforms of judicial councils usually relate public confidence to some other value (Table 1); most frequently these are independence (Netherlands, Poland, Italy, Hungary, Ireland), accountability (Netherlands), and the perception of the effectiveness of judicial system (Netherlands, Poland, Hungary, France, Ireland). Perhaps the most illustrative is the Dutch example, where the extensive research on the effectiveness of various JSG forms in other countries, ${ }^{40}$ as well as public confidence polls, preceded the establishment of the Council for the Judiciary. All in all, references to public confidence appear as one of the rationales justifying the establishment of a judicial council mostly after 1989, in countries introducing judicial councils in the last 10-15 years.

This section examined the expectations that both international and domestic reforms laid on judicial councils in relation to public confidence. In most of the cases, the legislative documents justified the reform or establishment of judicial councils by a need to increase the independence, legitimacy, or overall effectiveness of the courts. Public confidence had a certain place in these justifications, as both national and international rationales expected that the success of judicial councils in fulfilling the above-mentioned aims would translate into higher public confidence in the judiciary.

\section{Public Confidence in the Judiciary: Definition, Foundations, and Determinants}

As suggested above, judicial councils are often presented as a panacea for many disorders of the judicial system, from low judicial independence to ineffective and inefficient court management. They are expected to improve the quality of judicial systems, which should consequently be reflected in increased public confidence in the judiciary. However, public confidence is a multifaceted phenomenon, with plenty of various intervening factors and determinants that need to be taken into account. To examine the possible links with judicial councils, we first start with a comprehensive literature review and theoretical considerations about public confidence. This section offers a working definition of public confidence in the judiciary (Part I.), summarizes the main theories explaining how it emerges (Part II.) and, based on previous empirical research, examines its main determinants (Part III.).

\section{Defining Public Confidence in the Judiciary}

Questions regarding the trust and public confidence in political institutions, including the judiciary, have long been of interest for scholars in social sciences. As suggested by Sztompka ${ }^{41}$, there are some unique features of contemporary societies that give particular salience to this topic. We live in a complex and interdependent world with increasingly

\footnotetext{
${ }^{40}$ See supra note 4.

${ }^{41}$ PIOtR SZTOMPKA, TRust: A SOCIOlogical TheORY 11-15 (2000).
} 
numerous options to choose from, which, moreover, is becoming more and more opaque for us. Our existence and well-being progressively depend on people and institutions which are growingly anonymous and impersonal. Thus, to cope with these challenges, to be able to cooperate, and to not become paralyzed by uncertainty, we need to have enough trust in other people, as well as institutions. Trust and confidence are the social cement binding interpersonal relationships in society and encouraging sociability and participation. In this regard, public confidence in the judiciary is especially important, because courts and judges are the guarantors of justice to whom we resort in cases when our trust in other people or institutions fails us.

As is usually the case with broad concepts used across various disciplines, there is considerable disagreement on the definition of trust and confidence. First, these two concepts are very often used as synonyms, although sociology traditionally differentiates between them. In this respect, Luhmann ${ }^{42}$ distinguishes confidence, which refers to living with everyday dangers without being actively involved and considering alternatives ${ }^{43}$, and trust, which requires a previous engagement and presupposes a situation of risk where a trusting agent must accept responsibility for potential disappointment. From this point of view, when thinking about the general attitude of citizens towards the judiciary, usually measured in public opinion polls, it seems more appropriate to refer to confidence, as the vast majority of people do not have direct, first-hand experience with courts. Their relationship is more "detached, distanced, noncommittal". 44 The term trust in the judiciary should be reserved for situations in which people need to participate actively and face an unknown future, ${ }^{45}$ for instance, to choose whether to trust and turn to the court with their issue, or rather try to settle it on their own or via extrajudicial proceedings. It must be noted, however, that in practice, the majority of literature on public confidence in the judiciary seems not to distinguish between trust and confidence. Similarly, official international documents on JSG, as shown in Section B, use the terms interchangeably. Moreover, some studies use trust and public confidence in the judiciary as the main indicator of other concepts, like public support, ${ }^{46}$ esteem, $^{47}$ or social legitimacy. ${ }^{48}$

42 Niklas Luhmann, Familiarity, Confidence, Trust: Problems and Alternatives, in TRUST: MAKING AND BREAKING Cooperative Relations 94-107 (Diego Gambetta ed., 1988).

${ }^{43}$ E.g., normally, we are confident that when we leave our homes in the morning and go to work, there will not be a commando of snipers trying to shoot us down. Although it is possible, we bracket this option because it is highly improbable, and also because otherwise we would have to live in a state of permanent uncertainty.

${ }^{44}$ Sztompka, supra note 41 , at 25.

45 Id. at 25.

${ }^{46}$ E.g., Jeffery J Mondak \& Shannon Smithey Smithey, The Dynamics of Public Support for the Supreme Court, 59 THE JOURNAL OF POLITICS 1114-1142 (1997).

${ }^{47}$ E.g., Caldeira, supra note 13. 
Public confidence in the judiciary can be defined as positive expectations regarding the conduct of judges and courts. ${ }^{49}$ People have confidence in actors or institutions when they believe they will act "as they should". ${ }^{50}$ It is the public's belief in the reliability, honesty and ability of courts and judges, the belief that the courts "act competently in the sense that they are able to perform the functions that are legally or constitutionally assigned to them". ${ }^{51}$ The conceptualization of the lack of public confidence in the judiciary is of equal importance. It does not necessarily invoke a negative mirror-image of confidence cynicism, and alienation - but it can merely reflect "skepticism, an unwillingness to presume that political authorities should be given the benefit of the doubt". 52 Thus, when citizens claim in a public opinion poll that they do not have much or any confidence in the judiciary in their country, it does not necessarily mean that they consider the courts to be unfair, corrupt and incompetent. It can also mean that they are rather skeptical and suspicious and do not see enough reasons why they should grant them confidence. In practice, to be able to differentiate between the two groups and assess their size, we would need further and more detailed poll questions, which are usually missing.

From the time perspective, the level of public confidence reflects both short-term satisfaction with the performance of courts and judges (which can vary depending on, e.g. agreement with salient and important judicial decisions, or occurrence of ad hoc affairs and scandals), and long-term attachments and loyalty, which can cushion the impact of short-term dissatisfactions. ${ }^{53}$ Therefore, when examining the potential effect of judicial councils on public confidence in the judiciary, we will use longitudinal data to account for temporary increases and decreases.

From the viewpoint of targets of trust, Sztompka distinguishes between interpersonal trust/confidence in other actors with whom we come into direct contact (e.g., the judge who is handling our case), and its derivative, social trust/confidence towards more abstract

\footnotetext{
${ }^{48}$ E.g., Marc Bühlmann \& Ruth Kunz, Confidence in the Judiciary: Comparing the Independence and Legitimacy of Judicial Systems, 34 WEST EUROPEAN POLITICS 318 (2011).

49 Roy J. Lewicki, Daniel J. McAllister \& Robert J. Bies, Trust and Distrust: New Relationships and Realities, 23 ACADEMy of MANAGEMENT REVIEW 439 (1998).

50 Jack Citrin \& Christopher Muste, Trust in Government, in MEASURES OF POLITICAL ATTITUDES 465-532 (John Robinson, Phillip R. Shaver \& Lawrence S. Wrightsman eds, 1999).

${ }^{51}$ George W. Dougherty, Stefanie A. Lindquist \& Mark D. Bradbury, Evaluating Performance in State Judicial Institutions: Trust and Confidence in the Georgia Judiciary, 38 STATE AND LOCAL GOVERNMENT REVIEW 176 (2006).

52 Timothy E. Cook \& Paul Gronke, The Skeptical American: Revisiting the Meanings of Trust in Government and Confidence in Institutions, 67 THE JOURNAL OF POLITICS 785 (2005).

53 James L. Gibson, Gregory A. Caldeira \& Lester Kenyatta Spence, Measuring Attitudes toward the United States Supreme Court, 47 AMERICAN JouRnAL Of PolitiCAL SCIENCE 364 (2003).
} 
social objects, like social groups (e.g., judges as a professional group), institutions and organizations (e.g., courts), their practices (e.g., judicial procedures), or, at the most general level, social systems or regimes (e.g., the judicial system as a whole). ${ }^{54}$ Therefore, when examining the possible effects of judicial councils on the level of public confidence, we are using the broadest possible indicator - public confidence in the judiciary - to account for potential spillovers of confidence on various levels.

\section{Foundations of Public Confidence in the Judiciary}

Before investigating the mechanism of how judicial councils could enhance the level of public confidence in the judiciary, we first need to explore the foundations of confidence and its main determinants, and to place the factor of our interest - effects of judicial councils - within this context. After several decades of theorizing confidence, there are a plethora of theories aiming to explain how it is born, enhanced, maintained or lost. Based on these theoretical assumptions and expectations, how does public confidence in the judiciary emerge, what are its main sources and determinants, and what is the position of the factor of our interest - judicial councils - within this context?

There are two competing views of the main source of both trust and confidence. ${ }^{55}$ According to the first one, it is a default expectation of other individuals' goodwill based on individual dispositions (innate or learned early in life) to trust. Some people are inherently more optimistic and less worried that others will let them down, and even after potential disappointment, they try again. On the contrary, according to the relational view of trust and confidence, it is mostly a property of a social relation between two or more actors which "results from information about and past experience with the trustee and the situation at hand and is a prediction about another person's behavior" ${ }^{\prime 56}$. We argue that these two mechanisms are not mutually exclusive, but in practice, they are both involved, albeit to a varying extent. The tendency to place confidence in other people and institutions, including the judiciary, is an individual disposition, but as such, it is also culturally co-determined (on a collective level, long-term negative experiences and failed expectations of the political institution can be culturally reproduced and can instill a lack of public confidence in future generations). Moreover, this disposition is permanently confronted with everyday experiences, and it works as a prism through which we evaluate empirical evidence from everyday life and decide whether to change the dis/trusting attitude or not.

\footnotetext{
${ }^{54}$ Sztompka, supra note 41 , at 41-46.

55 ERIC M. USLANER, THE MORAL Foundations of Trust (2002).

${ }^{56}$ Sven Oskarsson, Torsten Svensson \& PerOla Oberg, Power, Trust, and Institutional Constraints: Individual Level Evidence, 21 RATIONALITY AND SOCIETY 173 (2009).
} 
Sztompka distinguishes three main grounds for trust and confidence: reflected trustworthiness (primary trust), contextual cues (secondary trust), and trust culture. ${ }^{57}$ From this perspective, public confidence in the judiciary is determined mainly by the perceived trustworthiness of the courts and judges, which is influenced not only by their performance, but also by their reputation (the record of past deeds), and appearance. To estimate the trustworthiness of the judiciary, the public needs some knowledge and information: courts and judges need to be transparent and visible enough, subordinated to unambiguous criteria and standards of performance, and citizens should have some competence to evaluate the cues of trustworthiness. The second determining set of factors relates to external context, e.g., accountability (presence of agencies enforcing the trustworthiness). Finally, the third ground for public confidence in the judiciary is rooted in the broader cultural context, in collective memory, and in shared values, norms and expectations.

All of these views, albeit to a different extent, are reflected in the three main theoretical traditions competing as an explanation for the origins of public confidence in institutions. First, social-psychological theories treat trust and confidence as basic aspects of personality types, which emerge in the first stages of psychological development. ${ }^{58}$ This view sees confidence in the judiciary at least to some extent as a given personality trait. Second, cultural theories hypothesize that confidence originates in long-standing and deep-seated beliefs about people that are the products of social experiences and socialization, and thus also have roots in cultural norms. ${ }^{59}$ Institutional confidence is an extension of interpersonal trust projected onto political institutions. According to these theories, public confidence in the judiciary is at least to some extent culturally determined and should differ between culturally distinct countries. Third, institutional theories emphasize institutional performance (the expected utility of institutions performing satisfactorily) instead. ${ }^{60}$ Based on these theories, public confidence in the judiciary is determined by its performance, which can include for instance efficiency, access, effectiveness, competence, equality, or fairness. Again, we see these theories as complementary rather than mutually exclusive. The three levels - individual, institutional and cultural - form the conceptual framework within which we examine the effects of judicial councils on public confidence.

\footnotetext{
${ }^{57}$ Sztompka, supra note 41 , at 69-101.

${ }^{58}$ Kenneth Newton \& Pippa Norris, Confidence in Public Institutions: Faith, Culture or Performance?, in DISAFFECTED Democracies: What's Troubling the Trilateral Countries? 56 (Susan J. Pharr \& Robert D. Putnam eds., 2000).

${ }^{59}$ William Mishler \& Richard Rose, What Are the Origins of Political Trust? Testing Institutional and Cultural Theories in Post-communist Societies, 34 Comparative Political Studies 30-62 (2001).

${ }^{60}$ Newton \& Norris, supra note 58, at 58.
} 


\section{Determinants of Public Confidence in the Judiciary: Review of Empirical Evidence}

Inasmuch as judicial councils can influence the functioning of courts, their existence (or lack thereof) and character naturally have a place among factors potentially influencing the level of public confidence in the judiciary. To evaluate their effect, we first need to ascertain other possible determinants. Based on the review of empirical studies on public confidence in political institutions in general, as well as in the judiciary in particular, we identified the main factors with statistically significant influence on confidence, and divided them into the three above-mentioned levels: individual traits, cultural characteristics, and factors related to institutional performance of state and judiciary.

On the individual level, almost all the empirical analyses confirm the existence of a relationship between various individual characteristics of citizens and the level of their confidence in the judiciary, although the evidence is very often conflicting. This is hardly surprising, given that the studies draw from different datasets from different countries collected in different time periods. Socio-demographic characteristics are among the most commonly explored variables. Numerous studies ${ }^{61}$ concluded that respondents with higher income and economic status have greater institutional confidence. Regarding the level of education, several US studies ${ }^{62}$ concluded that more educated respondents have more confidence in courts, while in selected Eastern European countries, education and institutional confidence was found to be negatively associated, ${ }^{63}$ and in other studies, education was a non-significant predictor. ${ }^{64}$ From the viewpoint of gender, according to some studies, women seem to have more confidence than men, ${ }^{65}$ although there are also analyses concluding the opposite. ${ }^{66}$ The same applies to age: most of the reviewed

\footnotetext{
${ }^{61}$ E.g., Bühlmann \& Kunz, supra note 48, at 332. Newton \& Norris, supra note 58, at 9. William Mishler \& Richard Rose, Trust, Distrust and Skepticism: Popular Evaluations of Civil and Political Institutions in Post-Communist Societies, 59 The Journal OF Politics 444 (1997). Ola Listhaug, Confidence in Institutions: Findings from the Norwegian Values, 27 ACTA SocIologICA 121 (1984). James W. Stoutenborough \& Donald P. Haider-Markel, Public Confidence in the U.S. Supreme Court: A New Look at the Impact of Court Decisions, 45 THE SOCIAL SCIENCE JOURNAL 38 (2008). Ryan Salzman \& Adam Ramsey, Judging the Judiciary: Understanding Public Confidence in Latin American Courts, 55 LATIN AMERICAN Politics 88 (2013).

${ }^{62}$ E.g., Stoutenborough \& Haider-Markel, supra note 61. Benesh, supra note 12. James P. Wenzel, Shaun Bowler \& David J. Lanoue, The Sources Of Public Confidence In State Courts: Experience and Institutions, 31 AMERICAN POLITICS RESEARCH 200 (2003).

${ }^{63}$ E.g., Kadri Lühiste, Explaining Trust in Political Institutions: Some Illustrations from the Baltic States, 39 COMMUNIST AND POST-COMMUNIST STUDIES 493 (2006).

${ }^{64}$ E.g., Bühlmann \& Kunz, supra note 48 , at 332. Mishler \& Rose, supra note 61 , at 445.

${ }^{65}$ E.g., Lühiste, supra note 63. Bühlmann \& Kunz, supra note 48, at 332. Newton \& Norris, supra note 58, at 9. Mishler \& Rose, supra note 61, at 445. Christine A. Kelleher \& Jennifer Wolak, Explaining Public Confidence in the Branches of State Government, 60 POLITICAL RESEARCH QUARTERLY 717 (2007).

${ }^{66}$ E.g., Stoutenborough \& Haider-Markel, supra note 61.
} 
studies ${ }^{67}$ claimed that older citizens exhibit higher confidence in institutions, but some found that it was vice versa, ${ }^{68}$ and another ${ }^{69}$ discovered no relationship between the two. Regarding ethnicity, the majority of the reviewed studies ${ }^{70}$ concluded that members of ethnic minorities have less confidence in political institutions, including the judiciary. On the contrary, according to another US study, ${ }^{71}$ Latinos have more positive dispositions towards the courts than their fellow citizens.

Besides socio-demographic characteristics, the direct and indirect experience of citizens may also be important. Interestingly, several studies reported a negative relationship between personal experiences with the court system (being a defendant in a criminal case or a party to a civil proceeding) and its evaluation: as experience increases, support decreases. $^{72}$ The only exception seems to be the experience of being a criminal juror in the US, which increases the level of confidence in the judiciary. ${ }^{73}$ Again, another study found no statistically significant relationship between experience with the courts and level of confidence in the judiciary. ${ }^{74}$ In addition, awareness and knowledge of the judiciary matter, although the results are once more conflicting: according to several US studies, ${ }^{75}$ more knowledgeable respondents are more supportive of courts, but an analysis focusing on Latin-American countries ${ }^{76}$ found an opposite relationship. The majority of citizens use the media as their main source of information about the judiciary; in this respect, several studies revealed that media consumption is positively associated with confidence in legal

\footnotetext{
${ }^{67}$ E.g., Mishler \& Rose, supra note 61, at 445. Newton \& Norris, supra note 58, at 9. Kelleher \& Wolak, supra note 65, at 717 . Listhaug, supra note 61.

${ }^{68}$ E.g., Stoutenborough \& Haider-Markel, supra note 61. Lühiste, supra note 63 , at 486.

${ }^{69}$ Bühlmann \& Kunz, supra note 48 , at 332.

${ }^{70}$ E.g., Lühiste, supra note 63 , at 491 . Kelleher \& Wolak, supra note 65 . Dougherty, Lindquist \& Bradbury, supra note 50. David B. Rottman \& Alan Tomkins, Public Trust and Confidence in the Courts: What Public Opinion Surveys Mean to Judges, 36 Court ReVIEW: The Journal of the AMERICAN Judges ASSOCIATION 24-31 (1999).

${ }^{71}$ Wenzel, Bowler \& Lanoue, supra note 62, at 202.

${ }^{72}$ E.g., Benesh, supra note 12, at 704. Wenzel, Bowler \& Lanoue, supra note 62, at 204. Thomas E. Fossati \& James W. Meeker, Evaluations of Institutional Legitimacy and Court System Fairness: A study of gender differences, 25 JOURNAL OF CRIMINAL JUSTICE 152 (1997).

${ }^{73}$ E.g., Wenzel, Bowler \& Lanoue, supra note 62, at 206.

${ }^{74}$ Salzman \& Ramsey, supra note 61 , at 89.

${ }^{75}$ E.g., Wenzel, Bowler \& Lanoue, supra note 62, at 202. Benesh, supra note 12, at 704. James L. Gibson, Gregory A. Caldeira \& Vanessa A. Baird, On the Legitimacy of National High Courts, 92 AMERICAN POLITICAL SCIENCE REVIEW 350 (1998).

${ }^{76}$ Salzman \& Ramsey, supra note 61 , at 88-89.
} 
authorities. $^{77}$ Political attitudes matter as well: people with more centrist views (supporting neither the extreme left nor right), ${ }^{78}$ with a stronger orientation towards liberty $^{79}$ and social order, ${ }^{80}$ who support the rule of law and democracy, ${ }^{81}$ have higher confidence in the judiciary. On the contrary, those with a greater preference for a stronger president exhibit less confidence. ${ }^{82}$ Finally, unsurprisingly, political winners, i.e., individuals supporting the party which is currently in power, display higher levels of institutional confidence. $^{83}$

Furthermore, still on the individual level, perception, and evaluation of the current economic situation, as well as of institutional performance (including the judiciary), have significant effects on public confidence. First, the better an individual perceives the economic conditions and the more optimistic she is about the future of the national economy, the stronger is her confidence in political institutions, including the judiciary. ${ }^{84}$ Second, evaluation of the performance of political institutions also plays a role. As shown by Mishler and Rose, ${ }^{85}$ in post-communist countries, people who think that the new regime has increased freedom and treats them more fairly than the old regime are much more likely to trust current political institutions, including the judiciary. In addition, several studies found a strong negative correlation between the level of perceived corruption and experience with corruption on the one hand, and the level of public confidence in political institutions on the other. ${ }^{86}$ Third, evaluation of the court system's performance matters, mostly regarding perceived fairness and agreement with court rulings. Several authors argue that the public does not evaluate the courts by focusing primarily on either performance or instrumental issues such as delays or costs, but instead, what matters is

\footnotetext{
${ }^{77}$ E.g., Kelleher \& Wolak, supra note 65. Yingyos Leechaianan, Seksan Khruakham \& Larry T. Hoover, Public Confidence in Thailand's Legal Authorities, 14 International Journal of Police SCIEnCE \& MANAGement 246-263 (2012).

${ }^{78}$ E.g., Listhaug, supra note 61.

${ }^{79}$ E.g., Stoutenborough \& Haider-Markel, supra note 61. Gregory A. Caldeira \& James L. Gibson, The Etiology of Public Support for the Supreme Court, 36 AMERICAN JOURNAL OF POLITICAL SCIENCE 658 (1992).

${ }^{80}$ E.g., Caldeira \& Gibson, supra note 79.

${ }^{81}$ E.g., Salzman \& Ramsey, supra note 61 , at 87.

${ }^{82}$ E.g., Salzman \& Ramsey, supra note 61.

${ }^{83}$ E.g., Bühlmann \& Kunz, supra note 48, at 332. Lühiste, supra note 63, at 491.

${ }^{84}$ E.g., Lühiste, supra note 63 . Mishler \& Rose, supra note 61, at 442.

${ }^{85}$ Mishler \& Rose, supra note 61 , at 441.

${ }^{86}$ E.g., Salzman \& Ramsey, supra note 61, at 87. Kelleher \& Wolak, supra note 67, at 718. Lühiste, supra note 63. Mishler \& Rose, supra note 61, at 48. Bianca Clausen, Aart Kraay \& Zsolt Nyiri, Corruption and Confidence in Public Institutions: Evidence from a Global Survey, 25 WORLD BANK ECONOMIC REVIEW 232 (2011).
} 
their perception of how the courts and judges treat the public, how fair the procedures are, and how the courts exercise their authority. ${ }^{87}$ Additionally, transparency and media coverage matter: if specific rulings reach the public on a larger scale, they can have a significant positive or negative impact on individual-level confidence in the courts. Disagreement with decisions (or at least with how they are interpreted) reduces confidence, while pleasing decisions increase it. ${ }^{88}$

Public confidence in the judiciary is also influenced by the amount of interpersonal trust and confidence (the tendency to trust other people). From the viewpoint of theories explaining the emergence of confidence, interpersonal trust and confidence are located on the borders between the individual and cultural levels. As already mentioned, it is to some extent a personal trait which is inborn and developed in early childhood, and to some extent, it is also culturally determined. According to cultural theories, interpersonal confidence is an attribute of national character, and it spills over to political institutions, and thus co-determines institutional trust. Several studies found that people and societies with relatively high levels of interpersonal trust and confidence tend to also have relatively high levels of confidence towards political institutions, including the judiciary. ${ }^{89}$ Nonetheless, Mishler and Rose ${ }^{90}$ found that in post-communist countries, this relationship is weak, and, surprisingly, negative.

Besides interpersonal confidence, another potential source of confidence in the judiciary is overall institutional confidence. It can be conceptualized as a cross-sectional determinant, because it partially stems from individual traits, from cultural norms, expectations, and beliefs, and also from the performance of the institutions and how it is perceived. Empirical studies focusing on various countries agree that overall confidence in political institutions, particularly national government and parliament, significantly correlates with confidence in the judiciary. $^{91}$

\footnotetext{
${ }^{87}$ E.g., Fossati \& Meeker, supra note 72. Tom R. Tyler, Public Trust and Confidence in Legal Authorities: What Do Majority and Minority Group Members Want from the Law and Legal Institutions?, 19 BEHAVIORAL SCIENCES AND THE LAW 233 (2001).

${ }^{88}$ E.g., Stoutenborough \& Haider-Markel, supra note 61, at 41. Anke Grosskopf \& Jeffery J. Mondak, Do Attitudes Toward Specific Supreme Court Decisions Matter? The Impact of Webster and Texas v. Johnson on Public Confidence in the Supreme Court, 51 POLITICAL RESEARCH QUARTERLY 651-652 (2016).

${ }^{89}$ E.g., Lühiste, supra note 63. Newton \& Norris, supra note 60, at 63. Kenneth Newton, Trust, Social Capital, Civil Society, and Democracy, 22 InTERnational Political SCIENCE ReVIeW 211 (2001).

${ }^{90}$ Mishler \& Rose, supra note 59 , at 46.

${ }^{91}$ E.g., Wenzel, Bowler \& Lanoue, supra note 62 , at 202 . Salzman \& Ramsey, supra note 61 , at 87 . Bühlmann \& Kunz, supra note 48, at 332. Benesh, supra note 12, at 704. Stoutenborough \& Haider-Markel, supra note 61 , at 41. Magali Rheault \& Bob Tortora, Confidence in Institutions: Africans Speak on the Meaning of Being Well Governed, 32 HARVARD INTERNATIONAL REVIEW 74 (2011).
} 
On the cultural level, it must be noted that people in post-communist countries tend to have less confidence in other people and political institutions. Markova suggests that the lack of trust and confidence is a product of previous oppression and totalitarian socialization which fostered feelings of fear and suspicion. ${ }^{92}$ Sztompka argues that communist societies developed a "bloc culture" with various traits and characteristics leading to the decay of trust. ${ }^{93}$ Moreover, trust and confidence can be eroded by dramatic and negatively perceived societal changes, ${ }^{94}$ such as transformation. The pains of the transformation process with its radical political, economic, and societal changes led to a "post-revolutionary malaise" and "the morning after syndrome", and with that to a further collapse of trust and confidence. ${ }^{95}$ Thus, to summarize, the Communist regime eroded trust in the state and its institutions, including courts and judges. The judicial profession suffered from low prestige (both in social and financial terms) ${ }^{96}$ and was considered to be unattractive and corrupt. It seems that judiciaries in many post-Communist countries did not manage to rid themselves of these legacies. According to Eurobarometer data, between 2004 and 2017, in the old EU member states, on average 57\% of citizens tended to trust their national justice/legal system, while in the new EU member states, it was only $36 \%{ }^{97}$

Finally, the level of public confidence in the judiciary is influenced by the performance of the courts and judges, and because confidence in the judiciary is closely intertwined with confidence in other political institutions, also by their performance. Regarding performance of the judiciary, previous research shows that higher judicial independence, as rated by country experts, has a positive effect on an individual's confidence in the judiciary. ${ }^{98}$ Regarding courts' activity and workload, it seems that the number of cases heard decreases the level of public confidence, ${ }^{99}$ but a greater number of appeals helps to increase it. ${ }^{100}$ Visibility of the judiciary, measured as the media exposure of courts and

\footnotetext{
92 IVANa Markova, Trust And Democratic TRAnsition in Post-Communist EURope 1-23 (2004).

${ }^{93}$ Sztompka, supra note 41 , at 152-153.

94 Roger Sapsford \& Pamela Abbott, Trust, Confidence and Social Environment in Post-Communist Societies, 39 COMMUNIST AND POST-COMMUNIST STUDIES 59-71 (2006).

${ }^{95}$ Id. at 160 .

96 Zdenek Kühn, The Judiciary in Central and EAstern Europe: MeChanical Jurisprudence in Transformation? 53 (2011).

${ }^{97}$ http://ec.europa.eu/commfrontoffice/publicopinion/index.cfm/Chart/index.

${ }^{98}$ E.g., Bühlmann \& Kunz, supra note 48, at 332. Salzman \& Ramsey, supra note 61.

${ }^{99}$ E.g., Stoutenborough \& Haider-Markel, supra note 61, at 41.

${ }^{100}$ E.g., Kelleher \& Wolak, supra note 65 , at 715.
} 
judges, has a positive effect on public confidence. ${ }^{101}$ The same applies for gender and ethnic diversity on courts: smaller disparities between the share of women and ethnic minorities in the population and in the courts increase public confidence in the judiciary. ${ }^{102}$ As per judicial selection method (appointment or election), some studies claim that it does not affect public confidence, ${ }^{103}$ but another study claims that states with elected judges have a lower level of confidence in the judiciary. ${ }^{104}$ The power of the judicial system, measured as the possibility of the courts to check the constitutionality of political decisions, seems to have no significant effect on individual confidence. ${ }^{105}$ Lastly, and not surprisingly, judicial actions can also have a significant effect on changes in public confidence. ${ }^{106}$

Regarding performance of the state and its institutions, the results of previous studies are yet again mixed. Higher income inequality and poverty rates decrease public confidence in political institutions, ${ }^{107}$ but unemployment rates, tax burdens or inflation seem to have no effect. ${ }^{108}$ Some studies found a negative relationship between crime rate and public confidence in the judiciary, ${ }^{109}$ others claim that this factor is not significant. ${ }^{110}$ Finally, political events and affairs do affect the level of public confidence in courts, although, naturally, no general conclusion can be drawn in this respect. ${ }^{111}$

\footnotetext{
${ }^{101}$ E.g., Stephan Grimmelikhuijsen \& Albert Klijn, The Effects of Judicial Transparency on Public Trust: Evidence From a Field Experiment, 93 PUBLIC AdMINISTRATION 1006-1007 (2015).

${ }^{102}$ E.g., Kelleher \& Wolak, supra note 65 , at 715.

${ }^{103}$ E.g., Wenzel, Bowler \& Lanoue, supra note 62, at 205. Anthony J. Nownes \& Colin Glennon, An Experimental Investigation of How Judicial Elections Affect Public Faith in the Judicial System, 41 LAW \& SOCIAL INQUIRY 56 (2016).

${ }^{104}$ E.g., Benesh, supra note 12, at 704.

${ }^{105}$ E.g., Bühlmann \& Kunz, supra note 48 , at 328.

${ }^{106}$ E.g., Caldeira, supra note 13 , at 1223.

${ }^{107}$ E.g., Jean M. Twenge, W. Keith Campbell \& Nathan T. Carter, Declines in Trust in Others and Confidence in Institutions Among American Adults and Late Adolescents, 1972-2012, 25 PSYCHOLOGICAL SCIENCE 1921 (2014).

${ }^{108}$ E.g., Kelleher \& Wolak, supra note 65. Caldeira, supra note 13, at 1219.

${ }^{109}$ E.g., Benesh, supra note 12 , at 704 .

${ }^{110}$ E.g., Caldeira, supra note 13, at 1219. Kelleher \& Wolak, supra note 67.

${ }^{111}$ E.g., Caldeira, supra note 13, at 1219.
} 


\section{How the Establishment of a Judicial Council Can Enhance Public Confidence in the Judiciary? Theoretical and Empirical Considerations}

Having identified the determinants that potentially influence public confidence in the judiciary, it is now time to focus on judicial councils and their location among other factors. As demonstrated in Section B, as well as in numerous articles analyzing the national level mechanisms of judicial self-governance included in this Special Issue, the establishment of judicial councils has been associated with diverse, yet invariably great, expectations. In short, judicial councils were expected to enhance the quality of the judiciary, usually via strengthening judicial independence and autonomy (according to the authors of this Special Issue, this was the main purpose for the establishment of judicial councils e.g. in Spain, Romania, Slovakia and Turkey), or via improving its effectiveness and efficiency (e.g., in the Netherlands). With some exaggeration, judicial councils are supposed to work as deus ex machina and resolve the seemingly unsolvable problems of judiciaries. If judicial councils manage to fulfill these expectations, they should improve both judicial system performance and public image, and, consequently, enhance public confidence in the judiciary. This section explores this link both theoretically and empirically. First, it introduces a concept map depicting how public confidence in the judiciary emerges and discusses the possible effects of judicial councils within this context (Part I.). Second, based on the national case studies in this volume, it reviews the extent to which judicial councils in ten countries ${ }^{112}$ fulfilled the expectations that were invested into them (Part II.). Third, based on longitudinal Eurobarometer survey data, it examines whether the countries with judicial councils enjoy higher levels of public confidence in the judiciary than the countries without judicial councils (Part III).

\section{How Can Judicial Councils Help to Raise the Level of Public Confidence in the Judiciary?}

Public confidence in the judiciary is an intricate and multifaceted phenomenon, which, as shown in the previous section, has a many determinants (Section B). Thus, to answer the question of how judicial councils are potentially able help to enhance public confidence, we need to place them into the wider context. To show how limited the potential role of judicial councils is, we present a concept map explaining how public confidence in the judiciary emerges.

The concept map (Figure 2) is based on the literature review introduced in Section C. It takes into account social-psychological, cultural and institutional theories, and a variety of variables which, according to empirical studies, were statistically significantly associated with the level of public confidence.

${ }^{112}$ France, Ireland, Italy, Netherlands, Poland, Romania, Slovakia, Slovenia, Spain, Turkey. 
Figure 2: Public confidence in the judiciary: a conceptual map (Source: authors)

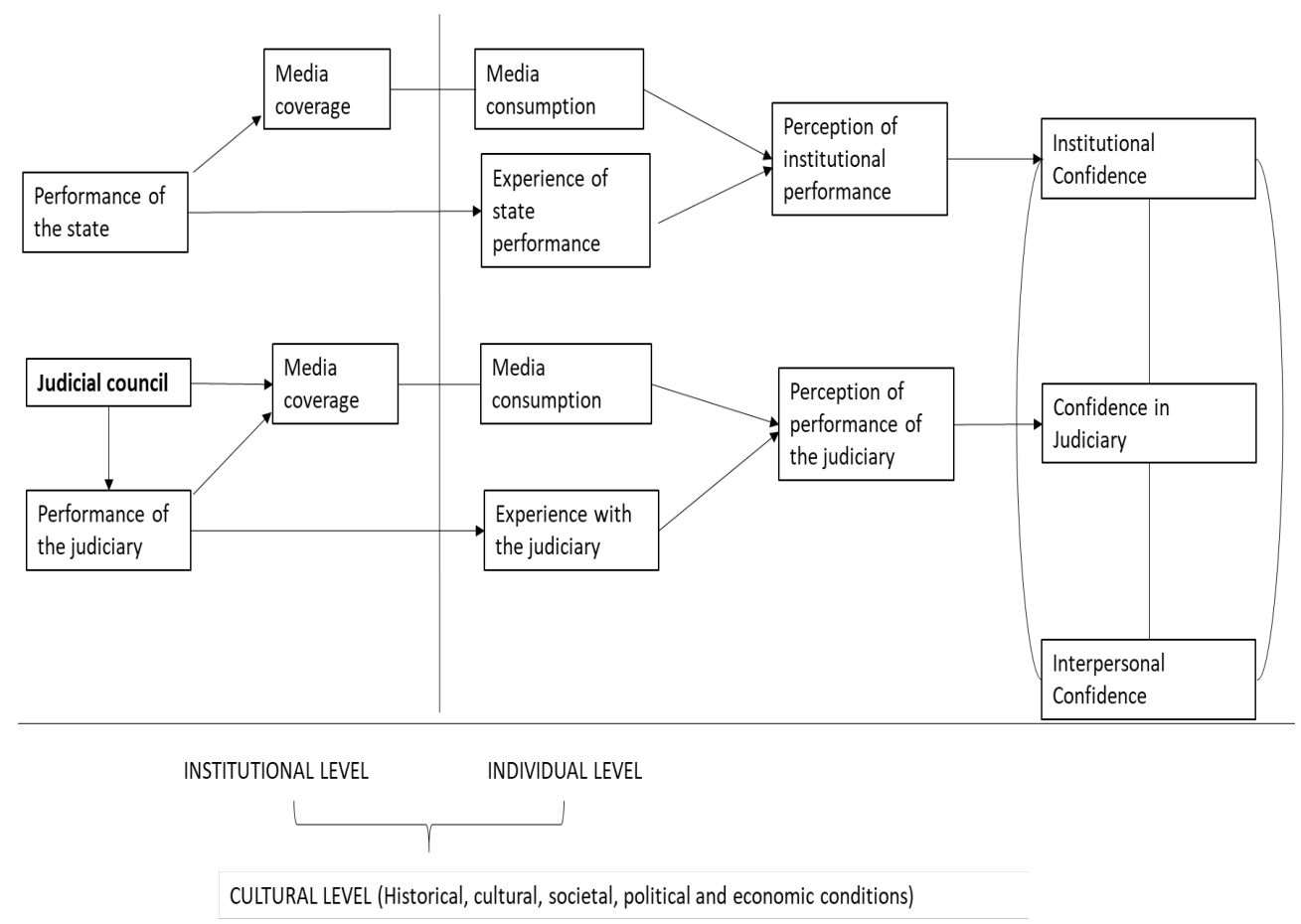

First, on the individual level, public confidence in the judiciary has three main sources. Our inclination to have confidence in the judiciary builds on our perception of its performance, which partially stems from our tendency to have confidence in other people (the amount of interpersonal trust/confidence), and in other political institutions, mostly government and parliament (the amount of institutional confidence). People form their opinions on the performance of the judiciary (e.g., perceived and experienced fairness and independence of judiciary; delays; costs; level of corruption; agreement with specific rulings; etc.) mostly based on how it is presented in the media, and, to a lesser extent, ${ }^{113}$ on their direct or indirect experience with judges and courts.

\footnotetext{
${ }^{113}$ In the 2013 Eurobarometer survey, a majority of respondents - 57\% - claimed to have no personal experience of any type of courtroom within the last ten years, and no close relative who has had this kind of experience. Source: European Commission, Justice in the EU. Flash Eurobarometer 385 (2013), http://ec.europa.eu/commfrontoffice/publicopinion/flash/fl_385_en.pdf2013 (last visited Oct. 12, 2018).
} 
Second, on the institutional level, what matters for building confidence is the actual performance of the judiciary (e.g., fairness; efficiency; independence; ease, and cost of access; effectiveness; competency; equality; etc.), as well as its media coverage.

The third, the cultural level (wider historical, societal, political, and economic conditions) is not linear but permeates both the institutional and individual levels. It affects not only the performance of political institutions, including the judiciary, and the way they are depicted in the media, but also the expectations and evaluations of the institutional performance by citizens. Thus, we claim that the trichotomy between social-psychological, institutional and cultural theories of public confidence is a false one and that they should rather be seen as mutually supplemental and interconnected layers of determinants of public confidence.

It must be noted that although, for the sake of simplicity, the concept map depicts the performance of the state and judiciary as the cause and public confidence as the effect, this relationship is not unidirectional. As suggested by Van de Walle and Bouckaert, performance has a certain impact on confidence, but the existing level of confidence may also have an impact on perceptions of performance. ${ }^{114}$

It follows from the above that the potential of judicial councils to affect the level of public confidence in the judiciary is very limited. Obviously, they cannot have any direct effect on the individual level, and they are too weak and subtle to affect the wider cultural level (it is rather the other way round, the cultural level may co-determine the existence and functioning of judicial councils). Nor can they affect the level of confidence in other political institutions or interpersonal confidence. Thus, the window of opportunity for judicial councils is very constrained: their effect on public confidence in the judiciary can only be traced on the institutional level, and even here they compete for competences and influence with other actors. They can enhance public confidence in the judiciary by improving the performance of courts and judges, and by improving their media coverage. For instance, if judicial councils manage to enhance the independence of the judiciary and increase its effectiveness and efficiency as promised, this improved institutional performance should lead to better media coverage of the judiciary and better personal experiences of citizens with judges and courts, and thus to higher public confidence. It must once again be noted that as the majority of citizens lack first-hand experience of the justice system, ${ }^{115}$ and do not feel well-informed about it, ${ }^{116}$ media coverage seems to be at least as important as institutional performance. It can be assumed that citizens are not much interested in nor are they knowledgeable about the institutional setup of the

\footnotetext{
${ }^{114}$ Steven Van de Walle \& Geert Bouckaert, Public Service Performance and Trust in Government: The Problem of Causality, 26 InTERnAtional Journal OF PUblic Administration 908-909 (2003).

${ }^{115}$ European Commission, supra note 113 , at 6.

${ }^{116}$ European Commission, supra note 113 , at 16.
} 
judiciary, and what matters for them is how persuasive the judges are in explaining their decisions in salient cases, how fair the judiciary seems to be to different societal groups (including the most and the least powerful), how often scandals and affairs regarding judges and courts occur (their absence, signaling the lack of self-cleaning mechanisms, can be as damaging as their all too frequent occurrence), and how other judges behave when these occur.

In other words, if judicial councils want to enhance the level of public confidence in the judiciary, they not only need to improve the quality of judicial systems noticeably, but they also need to be able to make this improvement visible and persuasive to the media and citizens. In this sense, trustworthy and active representatives of judicial councils who are willing and able to present the work of the council publicly, as well as to name and comment on the problems and sore spots of the judicial system instead of helping to hide them, are indispensable.

\section{II. (Mostly) Failed Expectations: Do Not Expect Independence and You Will Not Be Disappointed}

To summarize, the potential role of judicial councils in enhancing the level of public confidence in the judiciary is rather narrow: from the plethora of potential factors influencing public confidence, they can affect institutional performance and media coverage of the judiciary, and even these only partially. To further investigate this link on an empirical level, we need to explore to what extent the expectations of judicial councils have been fulfilled, and to what extent they have helped to improve the quality of judicial systems and their media representation. This endeavor is inescapably hindered by the lack of data and scholarly literature. As there is no comparable data on the media coverage of the judiciary in various countries, we focus solely on the extent to which judicial councils improved the quality of judicial systems. Even though the first judicial councils were established in the post-war era in the midst of 20th century, the literature assessing their impact has been very scarce. Fortunately, we can make use of the case studies presented in this Special Issue, and summarize their results.

Based on the case studies describing the functioning and effects of judicial councils in France, Italy, Poland, Spain, Turkey, Romania, Slovenia, Ireland, Slovakia, and the Netherlands, we can conclude that judicial councils rarely manage to improve the judicial systems that have been previously significantly flawed, but they are more successful in enhancing the quality of judicial systems which have already functioned quite well. In this sense, the effects of judicial councils resemble the biblical "Whoever has will be given more, and he will have an abundance. Whoever does not have, even what he has will be taken away from him." ${ }^{117}$ More concretely, when judicial councils are established with the

${ }^{117}$ MATTHEW 13:12. 
hope they will become guarantors of judicial independence in countries where independence of the judiciary has been an issue, they rarely seem to fulfill this expectation, and if they do, it is usually a long process. But if they are established in countries where independence of the judiciary has not been a concern, and they are instead expected to enhance effectiveness and efficiency, they seem to achieve their goals. This means, in line with O'Brien's argument, that a culture of judicial independence and respect for the independent role of the judiciary by all the stakeholders is more important than formal controls and institutional design. ${ }^{118}$ It also brings us back to the previously mentioned suggestion that judicial councils in new, emerging post-communist democracies faced huge risks if established within judiciaries which had not undergone any lustrations or other personnel exchange after the transition. ${ }^{119}$

In Romania, Slovenia, and Slovakia, the establishment of judicial councils aimed to secure the independence of the judiciary after the Communist regime, in compliance with the recommendation of the Council of Europe and the pressure from the European Commission. In Romania, as suggested by Selejan-Guțan ${ }^{120}$, the judicial council "was not sufficient for protecting the true independence of the judiciary", and the majority of citizens do not have confidence in the judiciary. In Slovenia, as Avbelj puts it, the judicial council has had a limited impact on independence, accountability, legitimacy, transparency of and confidence in the judiciary, and there have even been cases in which its (in)action negatively affected these values. ${ }^{121}$ Public confidence in the Slovenian judiciary is very low; it has been in persistent decline since 2007, and is today the lowest among all the Member States of the European Union. ${ }^{122}$ Regarding Slovakia, according to Spáč, Šipulová, and Urbániková, the link between the establishment of a judicial council and any potential improvement in these values is, at best, dubious. ${ }^{123}$ Moreover, Slovakia can serve as definite proof that the mere establishment of a judicial council does not automatically lead to higher public confidence in courts and the judiciary: public confidence in the Slovak justice/legal system constantly belongs among the lowest in the entire European Union. ${ }^{124}$ This is also due to the numerous scandals and affairs involving the top representatives of

\footnotetext{
${ }^{118}$ Patrick O'Brien, Never let a Crisis go to Waste: Politics, Personality and Judicial Self-Government in Ireland, in this issue.

${ }^{119}$ Kosař, supra note 18 .

${ }^{120}$ Bianca Selejan - Guțan, Romania: Perils of a "Perfect Euro-Model" of Judicial Council, in this issue.

${ }^{121}$ Matej Avbelj, Contextual Analysis of Judicial Governance in Slovenia, in this issue.

${ }^{122}$ Avbelj, supra note 121.

${ }^{123}$ Samuel Spáč, Katarína Šipulová \& Marína Urbániková' Capturing the Judiciary from Inside: The Story of Judicial Self-Governance in Slovakia, in this issue.

${ }^{124}$ European Commission, supra note 113, at 13.
} 
the judicial council. ${ }^{125}$ Although the institutional framework in these three countries gives "the impression of de jure impeccability", ${ }^{126}$ due mostly to cultural reasons (e.g. remnants of the Communist totalitarian past, formal and informal interpersonal networks between politicians and judges, judicial corporatism) as well as institutional reasons (e.g., insufficient organizational capacity for efficient functioning), at best, judicial councils did not manage to fulfill the expectations placed on them, and did not help to enhance public confidence in the judiciary. At worst, they may have even helped to decrease it.

Spain and Turkey offer a very similar story: what was expected from judicial councils, but remained undelivered, was once again judicial independence. Torres Pérez claims that in Spain, the political capture of judicial councils prevents it "from fulfilling its goal and has contributed to undermining public confidence in the judiciary as a whole". ${ }^{127}$ In Turkey, according to Çalı and Durmuş, it has been "suspect, whether the different forms of JSG have promoted judicial independence, given the highly politicized conditions that led to many of the JSG reforms". ${ }^{128}$

Regarding France, Italy, and Poland, we can note some mixed results: although the judicial councils helped to secure independence, other problems arose. Vauchez concludes that even though the judicial council in France "has undoubtedly gained competences and institutional autonomy, it remains firmly embedded in a dense web of links and dependences that secure its integration within the body of the State". ${ }^{129}$ Similarly, Benvenuti and Paris claim that in Italy, even though the High Council of the Judiciary played a crucial role in securing the independence of the judiciary from the executive power, this does not apply to the internal independence, and that "while securing the independence of the judiciary, the Italian model of JSG has been far less effective in making the judiciary accountable, which in turn may have affected professionalism and diminished public confidence." ${ }^{130}$ Finally, Śledzińska-Simon's analysis of the Polish case shows that even though in Poland (unlike in the above-mentioned post-communist countries), the Judicial Council succeeded as a guarantor of independence, this was not

\footnotetext{
${ }^{125}$ Spáč, Šipulová \& Urbániková, supra note 123.

${ }^{126}$ Avbelj, supra note 121.

${ }^{127}$ Aida Torres Pérez, Judicial Self-government and Judicial Independence: The Political Capture of the Judicial Council in Spain, in this issue.

${ }^{128}$ Başak Çalı \& Betül Durmuş, Judicial Self-Government as Experimental Constitutional Politics: The Case of Turkey, in this issue.

${ }^{129}$ Antoine Vauchez, The Strange Non-Death of Statism: Tracing The Ever Protracted Rise of Self-Government in France, in this issue.

${ }^{130}$ Simone Benvenuti \& Davide Paris, Judicial Self-Government in Italy: Merits, Limits and the Reality of an Export Model, in this issue.
} 
enough to enhance public confidence in the judiciary; under the slogan of democratization, the Government used the distance between the public and the judiciary to push through its judicial reform (2017) diminishing the position of the judicial council. ${ }^{131}$

There are two exceptions from these more or less skeptical national summaries: the Netherlands and Ireland. It seems that in both countries, judicial councils were established to improve the management of the courts, and they were not expected to become the guarantors of judicial independence, also because in both countries, the judiciary has traditionally enjoyed a high level of independence. In these cases, the promise has been fulfilled. Regarding Ireland, O'Brien argues that "the creation of the Courts Service has allowed the judiciary to improve the public image of the courts through improved facilities and have increased the transparency of the courts system through the Courts Service website and annual reports. It is possible that these changes have played a small role in enhancing public trust and improving the legitimacy of judges and the courts." 132 Mak concludes that "judicial self-government in the Netherlands can be assessed as functioning adequately" on the basis of a combination of rule-of-law values and new public management values (effectiveness, efficiency, and a client-oriented system), and that "there is a high level of trust in the Dutch judiciary, which steadily ranks at around $70 \%$ ". ${ }^{133}$ Curiously, in this case, the establishment and functioning of judicial councils led to concerns that the new public management approach puts judicial independence at risk: some judges did not feel represented by the Council, objected to the temporary appointment procedure for new court presidents, and claimed that the assessment of judicial performance had come to emphasize output too much. ${ }^{134}$ Thus, whereas the vast majority of countries establish judicial councils with the hope that they would secure independence, in the case of the Netherlands, the positive conclusion is that, fortunately, the judicial council did not put this value in danger.

\section{Empirical Evidence: Do Countries With Judicial Councils Enjoy Higher Levels of Public Confidence in the Judiciary?}

Based on the case studies focusing on the ten countries with judicial councils summarized above, we can conclude that in the majority of cases, the effects of judicial councils fell short of expectations, especially if they were supposed to strengthen and guarantee judicial independence. If judicial councils in the majority of cases do not help to substantially and visibly enhance the quality of judicial systems, there is no reason to

\footnotetext{
${ }^{131}$ Anna Śledzińska-Simon, The Rise and Fall of Judicial Self-Government in Poland: On Judicial Reform Reversing Democratic Transition in this issue

${ }^{132}$ O’Brien, supra note 118.

${ }^{133}$ Elaine Mak, Judicial Self-Government in the Netherlands: Demarcating Autonomy, in this issue.

${ }^{134}$ Mak, supra note 133.
} 
assume that they are able to increase the level of public confidence in the judiciary. As there are few examples of judicial councils delivering the expected results, we assume that, on average, judiciaries in countries with judicial councils do not enjoy higher public confidence than judiciaries in countries without judicial councils. To test this assumption, we examine longitudinal comparative Eurobarometer survey data on public confidence in the justice/legal system in all EU member states (representative national samples, > 15 year of age). To account for temporary increases and decreases caused by ad hoc factors, the analysis covers the time span between 2004 and 2017. Obviously, the data from public opinion polls do not allow us to move much beyond description: as demonstrated in previous sections, public confidence has a whole variety of determinants, and the existence and activity of a judicial council is only one of them. Thus, this analysis only reveals whether, in general, the countries with judicial councils are better off regarding public confidence, but it cannot serve as proof that higher or lower levels of public confidence are the consequence of the existence of a judicial council. In other words, the potential effects of judicial councils on public confidence can be only hypothesized.

As shown in Figure 3, regardless of the existence of a judicial council, citizens of the EU member states place greater confidence in the judiciary than they do in parliament or government, the other two branches of state power. In general, judiciaries in countries without judicial councils enjoy a higher level of public confidence than judiciaries in countries with them. In the former, between 2004 and 2017, on average 54\% of citizens claimed to have confidence in the judiciary, while in the latter, it was only $44 \%$. The level of public confidence in national parliament and government in both above-mentioned groups is identical: in countries with a judicial council, $33 \%$ of citizens tend to trust them, in countries without a judicial council, it is $38 \%$. 
Figure 3. Comparison of public confidence in parliament, government and judiciary in all EU countries with and without a judicial council from 2004 to 2017

(shares and standard deviations) $^{135}$

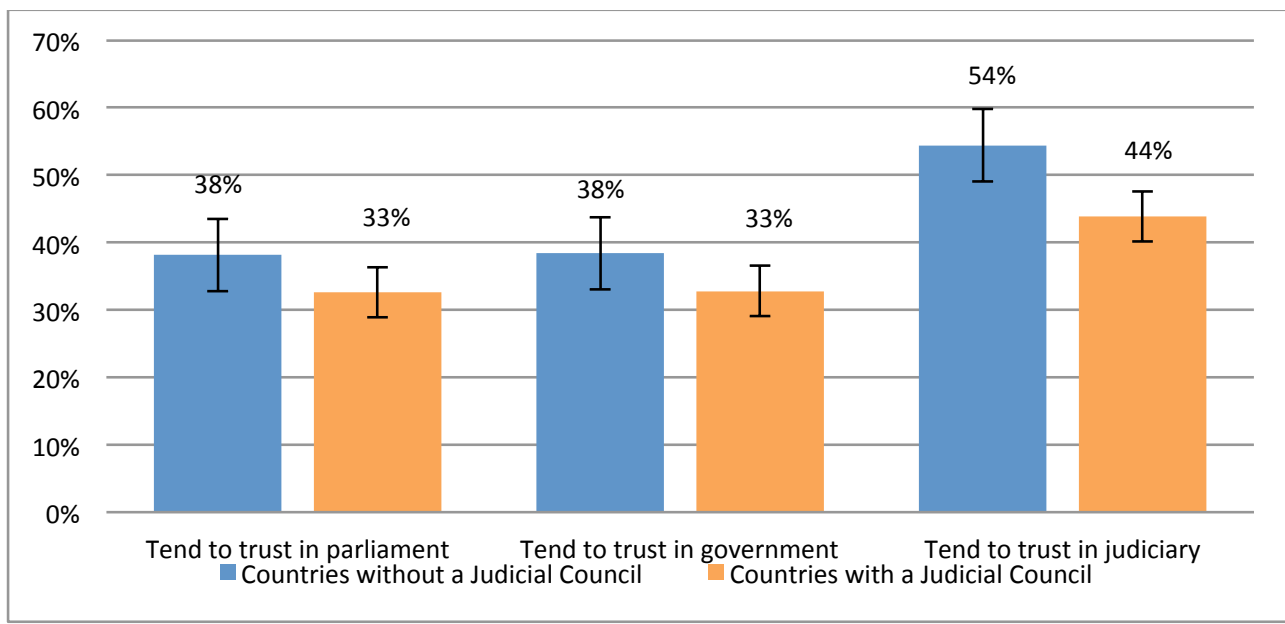

As mentioned in previous sections, public confidence in the judiciary correlates with public confidence in political institutions and interpersonal trust/confidence, and, for various reasons, both of these are lower in the post-communist countries. At the same time, the post-communist countries were pushed by the Councils of Europe and the European Commission to establish judicial councils. Thus, lower public confidence in the judiciary in the group of countries with judicial councils may be caused by the mere fact that the share of new EU member states, where citizens tend to be distrustful toward other people and political institutions, is higher in this group (10 new EU member states v. 9 old EU member states) than in the group of states without judicial councils (3 new EU member states v. 6

\footnotetext{
${ }^{135}$ Source: Eurobarometer, own calculation. Legend: The shares of trusting citizens are computed as averages of respondents claiming to tend to trust in the respective institutions between October 2004 (the first Eurobarometer round when the data were collected in both the old and new EU member states), and November 2017. In all the countries under examination, judicial councils were established before 2004, with the only exception being Latvia which established its judicial council in 2010 (nevertheless, Latvia was included into the group of countries with a judicial council).

Countries without a judicial council: Austria, Croatia, Cyprus, Czech Republic, Finland, Germany, Greece, Luxembourg, United Kingdom.

Countries with a judicial council: Belgium, Bulgaria, Denmark, Estonia, France, Hungary, Ireland, Italy, Latvia, Lithuania, Malta, Netherlands, Poland, Portugal, Romania, Slovakia, Slovenia, Spain, Sweden.

Question wording: I would like to ask you a question about how much trust you have in certain institutions. For each of the following institutions, please tell me if you tend to trust it or tend not to trust it? National parliament, National government, National justice/legal system.
} 
old EU member states). To account for this effect, in Figure 4, we compared the level of public confidence between four groups of countries: the new EU member states with and without a judicial council, and the old EU member states with and without a judicial council.

It is obvious that the gap in institutional confidence between the new and the old EU member states persists: the level of public confidence in parliament, government, and the judiciary is considerably higher in the old EU countries. The highest level of public confidence is enjoyed by judiciaries in the old EU member states without judicial councils ( $63 \%$ of citizens tend to trust), followed by, with a $10 \%$ margin, the judiciaries in the old EU member states with judicial councils (53\% tend to trust). In the new EU member states, only slightly more than one-third of citizens have confidence in the judiciary, regardless of the existence of a judicial council.

Figure 4: Comparison of public confidence in parliament, government and judiciary in the new and old EU countries with and without a judicial council from 2004 to $2017^{136}$

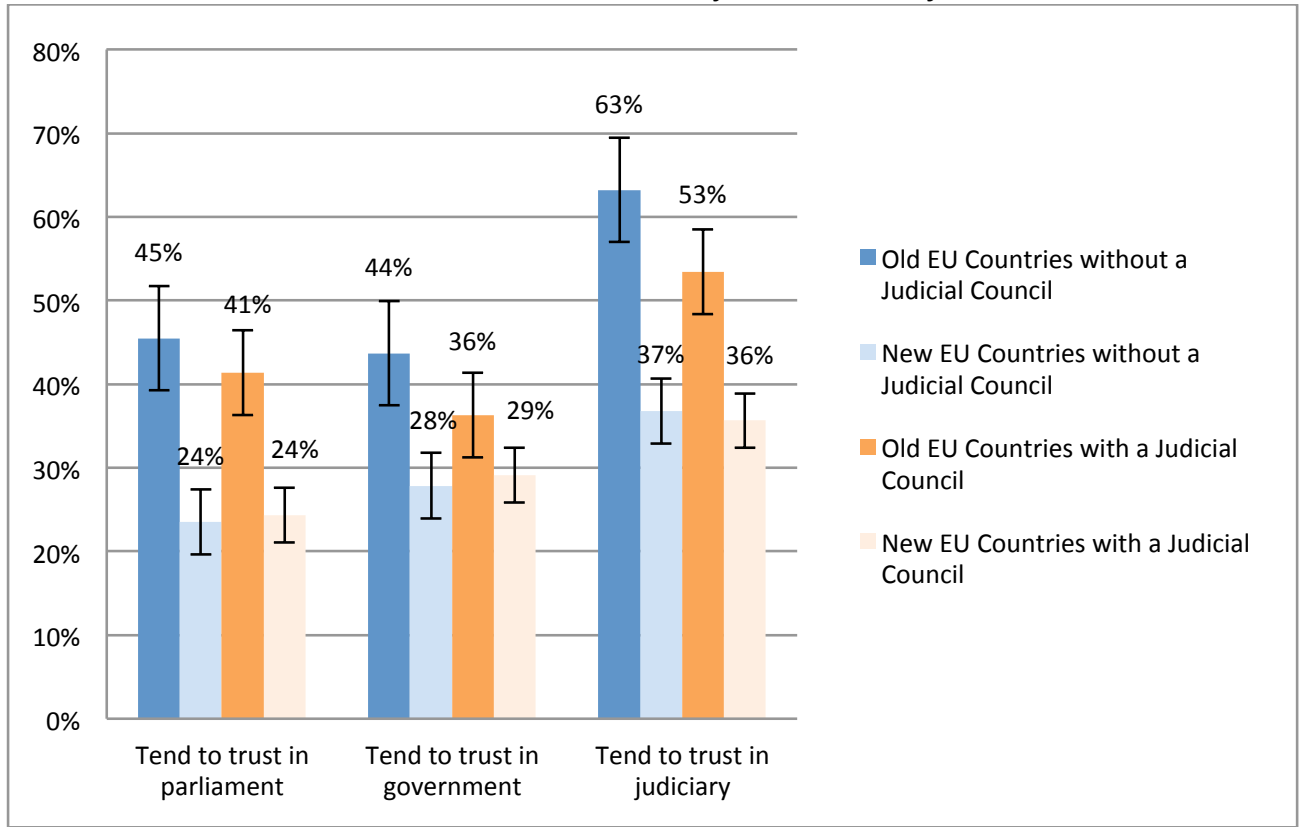

\footnotetext{
${ }^{136}$ Source: Eurobarometer. For Legend, see supra note 135. New EU member states: Croatia, Cyprus, Czech Republic, Bulgaria, Estonia, Hungary, Latvia, Lithuania, Malta, Poland, Romania, Slovakia, Slovenia. The same timeframe (2004-2017) was applied to Bulgaria, Romania and Croatia, even though they became members of the EU in 2007 and 2013, respectively (however, the data is available since 2004). Old EU member states: Austria, Finland, Germany, Greece, Luxembourg, United Kingdom, Belgium, Denmark, France, Ireland, Italy, Netherlands, Portugal, Spain, Sweden.
} 
In summary, it can be concluded that a) judiciaries enjoy higher public confidence than the other two branches of state power, b) institutional confidence, including confidence in the judiciary, is still considerably higher in the old EU member states than in the new ones, and c) regarding the level of public confidence in the judiciary, in the new EU member states, the existence of judicial councils does not make a difference, while in the old EU member states, judicial systems with judicial councils enjoy lower levels of public confidence than the ones without them.

It has to be stated once again that based on the descriptive data, we cannot conclude with certainty to what extent the differences in the level of public confidence in the judiciary between the countries with and without judicial councils are caused by the effects (or the lack) of judicial councils. Public confidence is a complex phenomenon with plenty of possible determinants, and the data presented above do not allow us to separate the effect of judicial councils from the effects of other factors. Moreover, what is dubious is not only the existence of the effect of judicial councils on the level of public confidence in the judiciary, but also the direction of this relationship. As presented in Section $B$, judicial councils were usually established in reaction to particular problems and issues that were troubling the judiciaries: mostly flawed judicial independence, or, less often, the effectiveness and efficiency of court management. We therefore assume that, due to these drawbacks, these judiciaries may have already induced a lower level of public confidence, and hence, the lower public confidence may not be the consequence, but rather an antecedent, of the creation of judicial councils. After all, it is always easier to push ahead the creation of a new body when the current state of the art is unsatisfying; on the contrary, the motivation to change the institutional setup of a well-working judicial system is, naturally, much lower. Unfortunately, given that many judicial councils were established several decades ago, we do not have the data to test this assumption and examine the level of public confidence before and after the introduction of judicial councils.

\section{E. Conclusion: The (False) Promise Broken?}

Judicial councils emerge with very diverse aims, typically focusing on the enhancement of the independence, and efficiency and effectiveness of judicial systems. If successful, their existence and functioning should lead to better working courts, and, consequently, to higher public confidence in judicial systems. After the major wave of the establishment of judicial councils that occurred in the last decades, it is about time to stop and review the extent to which judicial councils managed to fulfill the high hopes that were invested into them. This paper focused on the thus far neglected questions of how judicial councils can contribute to higher public confidence in the judiciary, what the empirical evidence looks like in this regard, and whether the countries with judicial councils enjoy higher public confidence than the countries without them.

Public confidence in the judiciary is a complex and multifaceted phenomenon with a plethora of determinants, which makes the exploration of the possible effects of judicial 
councils a challenging endeavor. Public confidence in judiciary emerges in an interplay between citizens' perceptions on the one hand, and performance of the judiciary on the other hand. People evaluate judicial systems mostly based on media coverage, and, to a lesser extent, based on their personal experiences with courts and judges. However, as the media creates reality at least as much as it reflects it, and as personal experience with the judiciary is usually quite rare and by no means representative, the link between perception of the judiciary and its performance is far from straightforward and mirror-like. Moreover, people's evaluations are a function of their expectations, which are partially subjective and variable, and partially rooted in shared cultural norms, values and beliefs - and none of these are in the hands of the judiciary or judicial councils. Finally, the tendency to have confidence in the judiciary is often influenced by the individual tendency to have confidence in other people and institutions in general, and by confidence in parliament and government in particular (because citizens often perceive the three main branches of power as "the establishment" and evaluate it together). This does not undermine the importance or relevance ${ }^{137}$ of public confidence in the judiciary. It merely shows how complex and potentially fragile it is, and how difficult it is to strategize on how to enhance it or to measure any impact.

In this broad context, judicial councils have some, albeit rather narrow, potential to affect public confidence, mostly via improving the performance of the judiciary and its media image. Moreover, if judicial councils are to enhance public confidence, their representatives should induce trust and should not get involved in scandals and affairs (as self-evident as it may seem, some case studies from this Special Issue suggest that not all top figures in judicial councils have managed to do so). On the contrary, they should be able and willing to comment on and criticize the weak points (and weak figures) of the judiciary, assure the public that they are being taken seriously, and suggest remedies.

Based on the national case studies summarizing experiences with the functioning of judicial councils included in this Special Issue, it seems that judicial councils rarely manage to significantly improve institutional performance. They can enhance the quality of judicial systems that have already functioned quite well, but they do not tend to bring about change in the judicial systems that have been previously significantly flawed. More concretely, when judicial councils are established with the hope to become guarantors of judicial independence in countries where independence of the judiciary has been an issue, they do not seem to fulfill this expectation, or it is a lengthy process with mixed results. But, if they are established in countries where independence of the judiciary has not been a concern, and they are instead expected to enhance effectiveness and efficiency, they seem to achieve their goals. Nonetheless, the majority of countries reviewed in this Special

\footnotetext{
${ }^{137}$ After all, as the Thomas theorem says, "If men define situations as real, they are real in their consequences". Thus, citizens act according to their level of confidence in the judiciary, even though their perception does not necessarily need to be objective. WILLIAM ISSAC THOMAS \& DOROTHY SWAINE THOMAS, THE CHILD IN AMERICA: BEHAVIOR PRoblems AND PROGRAMS 571-572 (1928).
} 
Issue fall within the first, not the second scenario. In these cases, if judicial councils do not help to substantially and visibly enhance the quality of the judicial system, there is no reason to assume that they are able to increase the level of public confidence in the judiciary.

Finally, the analyses of the longitudinal comparative Eurobarometer data revealed that, on average, the EU countries without judicial councils are better off in terms of public confidence (by a 10\% margin). Next, the citizens of both old and new EU states, regardless whether judicial council exists in their country or not, report higher confidence in the judiciary than other branches of state power (parliament or government). It must be noted that the gap in institutional confidence between the new and the old EU member states persists, with the citizens of the latter much more likely to have confidence in the judiciary, as well as parliament and government (by roughly one-third). After this was accounted for, the comparison revealed that in the new EU member states, the existence of judicial councils does not make a difference regarding public confidence in the judiciary, while in the old EU member states, judicial systems with judicial councils enjoy lower levels of public confidence than the ones without them.

That being said, this does not necessarily mean that the existence of a judicial council is to be blamed for lower public confidence. As already mentioned, the judicial councils have only limited power to deal with the structural causes of the lack of public confidence in the judiciary, which often has deeper cultural and societal roots. Also, based on the descriptive data, it is not possible to assess if and when public confidence decreased or remained low precisely due to judicial councils. Too many factors influencing public confidence remain hidden in a black box, and to assess other determinants of public confidence and isolate the effect of judicial councils, more empirical research is needed. Moreover, it is important to note that judicial councils seem to have emerged mostly in those systems which faced certain systemic problems, typically the lack of independence or low effectiveness of the courts, and therefore lower public confidence may be an antecedent rather than a consequence of the establishment of judicial councils. The evidence at hand only allows us to conclude that, in the majority of countries, judicial councils do not seem to fulfill the expectations that were invested into them nor do they significantly improve the quality of judiciaries, and consequently, they cannot enhance public confidence at least to the level enjoyed by the countries without judicial councils. We will never know how the systems would behave had the judicial councils not been established, though. 